\title{
28 Resarach Soure \\ Cadmium (Cd) Reduction Bacteria From Northern Coast Sediment Indramayu, Indonesia
}

\author{
Yudi lhsan ( $\nabla$ yudi.ihsan@unpad.ac.id) \\ Universitas Padjadjran, Indonesia \\ Tri Pribadi \\ Universitas Padjadjran, Indonesia \\ Kalysta Fellatami \\ Ocean University of China
}

\section{Research Article}

Keywords: Bacteria, 16S rRNA gene, Cadmium metal, Phylogen

Posted Date: May 6th, 2021

DOI: https://doi.org/10.21203/rs.3.rs-492778/v1

License: (c) (1) This work is licensed under a Creative Commons Attribution 4.0 International License. Read Full License 


\section{Abstract}

Cadmium (Cd) is one of the metals that contaminates Karangsong and has found several bacteria that can reduce cadmium (Cd). The purposes of this research are to obtain the type of bacteria and obtain an evolutionary relationship of cadmium (Cd) reduction bacteria from sediments in Karangsong Beach, Indramayu. The method used in this research is an exploratory method and the resulting data is analyzed descriptively. The molecular identification method uses $16 \mathrm{~S}$ rRNA gene which is a universal primer for bacteria. The bacterial sequences obtained were analyzed with GenBank data from the NCBI website. The results showed that two bacterial isolates were identical to the Pseudoalteromonas issachenkonii strain KMM 3549 (Acc. No. NR 025139.1) with 77\% identity value and 100\% evolutionary relationship value and Pseudoalteromonas tetraodonis GFC strain IAM 14160 (Acc. No. NR 041787.1) with identity values $97 \%$ and evolutionary value $99 \%$.

\section{Introduction}

Marine pollution has recently become a problem that threatens the earth and continues to be discussed by the international community. The rapid development of industry can have a negative impact on the environment, especially the marine environment. Pollutant wastes can cause large amounts of heavy metal content in seawater; this will have a negative impact on the survival of marine ecosystems and other living things, especially humans ${ }^{1}$. Several sources of heavy metals in marine waters can come from mining, agricultural waste and industrial waste ${ }^{2}$. Wastes produced from industry are generally heavy metals such as $\mathrm{Hg}, \mathrm{Cd}, \mathrm{Cu}, \mathrm{Zn}$ and $\mathrm{Ni}$ which are included in the category of Hazardous and Toxic Materials (B3) ${ }^{3}$.

Heavy metal pollution has also occurred in the Karangsong Beach area as an area with rapid industrial growth which also has a quite complex industrial waste problem. One of the reasons of the high pollution case in Karangsong is because it has one of the largest fish auction sites (TPI) in West Java, therefore the high activity of fishermen who mostly use diesel, gasoline and also disposal of waste oil from PT. Pertamina resulting in a high pollution to its waters. Various studies show that most of the waters in the Karangsong Coast area are contaminated with heavy metals, especially Cd. Efforts to control heavy metals by developing a consortium of indigenized bacteria as a bioremediation agent for Cd metal pollution in waters contaminated with industrial waste in Karangsong Beach, Indramayu Regency, are strategic steps to fight this problem. These bacteria are known to reduce the concentration of Cadmium (Cd) metal as a bioremediation agent. These bacteria can be identified by their types and relationships through molecular identification using PCR (Polymerase Chain Reaction) techniques using the 16S rRNA gene.

The primer used in the bacterial DNA amplification process is the 16S rRNA gene. The use of the 16S rRNA gene is based on the size of about 1550 base pairs and about 500 bases at the end of the sequence is an area called the hypervariable region. This area is the part that differentiates between organisms. Primers used in sequence amplification will recognize conserved regions and amplify hypervariable 
regions, thereby obtaining sequences that are unique to these organisms ${ }^{4}$. The purpose of this research was to obtain the types of bacteria and the relationship of the cadmium (Cd) reducing blood bankers from the sediments of Karangsong Beach, Indramayu.

\section{Results}

Sampling and Water Data. The water conditions of Karangsong Port are very murky, dark brown in color, have a very dense mud texture and a stinging odor. The parameters used to measure the quality of the waters of Karangsong Port are Temperature, DO, $\mathrm{pH}$ and salinity. The quality of Karangsong Waters is shown in Table 1.

\begin{tabular}{cc}
\hline Parameter & Value (unit) \\
\hline Temperature & $32{ }^{\circ} \mathrm{C}$ \\
pH & 6.80 \\
Dissolved Oxygen (DO) & 5.62 \\
Salinity & $29.7 \mathrm{mg} . \mathrm{L}^{-1}$ \\
\hline Depth & $50 \mathrm{~cm}$ \\
\hline Table 1. Karangsong Water Ouality
\end{tabular}

According to the quality standard of KMN-KLH PP No.1 Year 2010 on the conduct of water pollution control, the value of $\mathrm{pH}$ parameter which categorized as normal is 6 - 9 . The value of DO (dissolved oxygen) obtained is 5.92, dissolved oxygen is one of the important components in water quality. The average salinity value obtained is 29.7 this indicates that the sampling location is in the estuary area where this area has a salinity range between $5-35$ ppt. salinity also has a role in the solubility of heavy metals, the higher the salinity then the higher the content of heavy metals is due to the disruption of the oxidation process of the heavy metals ${ }^{5}$.

Cadmium Metal Concentration Reduction Test (Cd). Reduction of Cadmium (Cd) heavy metal concentrations was done by experimental test using indigenous bacteria from Karangsong Port.

A treatment with the $1.5 \mathrm{mg}$. $\mathrm{L}^{-1}$ concentration, it was able to lower the $\mathrm{Cd}$ concentration to $0.68 \mathrm{mg}$. $\mathrm{L}^{-1}$ at $48^{\text {th }}$ hours; the lowest concentration was 0.653 at $6^{\text {th }}$ hours (Fig. 1a). At a treatment of $1{\mathrm{mg} . \mathrm{L}^{-1}}^{-1}$ concentration, it could lower the $\mathrm{Cd}$ concentration to $0.48 \mathrm{mg} . \mathrm{L}^{-1}$ at $48^{\text {th }}$ hours; the lowest concentration was 0.445 at the $6^{\text {th }}$ hours. At a treatment where the concentration was $0.5 \mathrm{mg}$. $\mathrm{L}^{-1}$, it was able lower the Cd concentration to $0.32 \mathrm{mg}$. $\mathrm{L}^{-1}$ at 48 hours; with the lowest concentration of 0.271 in the $12^{\text {th }}$ hours.

The gene that can cause bacteria to be resistant to the heavy metal cadmium is the cad A-operon gene ${ }^{6-7}$ so it is thought that the bacteria taken at Karangsong Port have that gene. The bonding of heavy metals in a solution is by the exchange of ions where the ions in the cell wall of microorganisms are replaced by heavy metal ions ${ }^{8}$. The highest $\mathrm{Cd}$ reduction weight was $56.47 \%$ in $\mathrm{C}$ treatment $\left(1.5 \mathrm{mg} . \mathrm{L}^{-1}\right)$ after 6 hours of the treatment, meanwhile the lowest $\mathrm{Cd}$ reduction weight was $45.8 \%$ after 12 hours in the treatment $\mathrm{A}$ 
$\left(0.5 \mathrm{mg}^{-1} \mathrm{~L}^{-1}\right)$ (Fig. 1b). There are several factors that affect the reduction or absorption process of heavy metals, including phenotype factors, biomass factors, and medium factors.

Isolation of Metal Reduction Bacteria Cd. The bacterial samples used were bacteria samples that were not previously given $70 \%$ alcohol, so that they were found to be resistant to heavy metals. Bacterial samples were incubated for 48 hours at $37^{\circ} \mathrm{C}$ and subsequently bacterial colonies were obtained (Fig. 2).

The bacterial morphology identification in Table 2 follows the guidelines ${ }^{9}$. The ability of bacteria to form genetically colored dyes has become special markers for this bacteria type ${ }^{10}$. Bacterial purification perform after identification process. The purpose of bacterial purification is to obtain pure isolates that have the same morphological characteristics and gram type. Bacterial purification is done twice to ensure that the purified bacteria are pure. The results of bacterial purification can be seen in Fig. 3. The macroscopic bacterial colony morphology of the NA medium is presented in the following table;

\begin{tabular}{ccccc}
\hline Isolate Codes & \multicolumn{4}{c}{ Colony Features } \\
\cline { 2 - 5 } & Size & Elevation & Shape & Color \\
\hline A1 & Large & Plateau & Irregular & Yellowish white \\
A2 & Moderate & Flat & Round & Yellowish white \\
A3 & Small & Flat & Spindle & Transparent white \\
\hline A4 & Moderate & Flat & Round & Transparent white \\
\hline A5 & Small & Convex & Spindle & Yellowish white \\
\hline A6 & Small & Flat & Round & Transparent white \\
\hline A7 & Small & Flat & Irregular & Transparent white \\
A8 & Moderate & Convex & Round & Yellowish white \\
\hline
\end{tabular}

Table 2. Bacterial Macroscopic Morphology

Gram Staining. Gram staining was performed to identify the bacteria into two groups, namely gramnegative bacteria and gram-positive bacteria. The gram staining technique usually use alcohol and iodine, use dyes as well namely crystal violet and safranin. This observation is carried out microscopically using a microscope with a magnification of 1000x. The results of the gram stain can be seen in Supplementary Table 1.

The results of gram staining shows that the eight pure isolates tested were gram-negative bacteria, these results are in accordance with the statement in previous studies ${ }^{11}$, that gram-negative bacteria are generally more tolerant of the influence and exposure to heavy metals than gram-positive bacteria, this is because gram negative bacteria have a complex cell structure and which can bind and immobilize most of the heavy metal ions. Based on Supplementary Table 1, the form of bacterial cells obtained is generally in the form of diplobacilli (A1, A4, A6, A7 and A8) due to the shape of the bacterial cell resembles as a stem and forms two chains, meanwhile in isolate codes $A 2, A 3$ and $A 5$ the bacterial cells are oval or coccobacillus. This is in accordance with the statement from previous study ${ }^{12}$ that $80 \%$ of bacteria found in the sea are rod-shaped. 
Test Challenge of Bacteria to Cadmium Metal (Cd). Heavy metal challenge test aims to see the resistance of bacteria to heavy metals. According to another study regarding the bacterial resistance test ${ }^{13}$, the test of bacterial isolate resistance refer to obtain bacterial isolates that are resistant to heavy metals. Isolate of the 8 bacterial, merely 5 isolate of bacterial were truly pure bacteria, namely $\mathrm{Cd} 2, \mathrm{Cd} 3, \mathrm{Cd} 5, \mathrm{Cd} 6$ and $\mathrm{Cd}$ 7. These bacteria are known to reduce cadmium concentrations from $1.5 \mathrm{mg} . \mathrm{L}^{-1}$ to $0.681 \mathrm{mg} . \mathrm{L}^{-1}$ and bacterial growth from $1 \times 10^{6} \mathrm{CFU} / \mathrm{ml}$ to $19 \times 10^{6} \mathrm{CFU} / \mathrm{ml}$.

Bacterial isolates that were considered pure then subjected to a challenge test to cadmium (Cd) metal. Optical Density (OD) values were measured at 0 and 18 hours, furthermore most of bacterial growth was seen from the increase in Optical Density (OD) values at 0 and 18 hours. The results of the challenge test are listed in Table 3.

\begin{tabular}{ccccccc}
\hline $\begin{array}{c}\text { Bacteria } \\
\text { Code }\end{array}$ & $\begin{array}{c}\text { Optical } \\
\text { Density (OD) }\end{array}$ & $\begin{array}{c}\text { Bacterial } \\
\text { Density }\end{array}$ & $\begin{array}{c}\text { Optical } \\
\text { Density (OD) }\end{array}$ & $\begin{array}{c}\text { Bacterial } \\
\text { Density }\end{array}$ & $\begin{array}{c}\text { Optical } \\
\text { Density (OD) } \\
\text { initial }\end{array}$ & \multicolumn{2}{c}{ end } & $\begin{array}{c}\text { Bacterial } \\
\text { Density }\end{array}$ \\
\hline Control & 0 & 0 & 0 & 0 & 0 & 0 \\
Cd 2 & 0.0773 & $6.18 \times 10^{7}$ & 1.5863 & $1.27 \times 10^{9}$ & 1.509 & $1.21 \times 10^{9}$ \\
Cd 3 & 0.0915 & $7.32 \times 10^{7}$ & 2.02253 & $1.62 \times 10^{9}$ & 1.931 & $1.54 \times 10^{9}$ \\
Cd 5 & 0.0843 & $6.74 \times 10^{7}$ & 2.05777 & $1.65 \times 10^{9}$ & 1.973 & $1.58 \times 10^{9}$ \\
Cd 6 & 0.0905 & $7.24 \times 10^{7}$ & 1.81877 & $1.45 \times 10^{9}$ & 1.728 & $1.38 \times 10^{9}$ \\
Cd 7 & 0.0725 & $5.8 \times 10^{7}$ & 1.94043 & $1.55 \times 10^{9}$ & 1.868 & $1.49 \times 10^{9}$ \\
\hline
\end{tabular}

Table 3. Optical Density (OD) Value at $\mathrm{t}=0$ and $\mathrm{t}-18$

The Optical Density (OD) value shows the level of bacterial density. Based on the results, the change in the Optical Density (OD) value sequentially from highest to lowest were isolate Cd 5 (1.973); isolate Cd 3 (1.931); isolate $\mathrm{Cd} 7$ (1.868); isolate $\mathrm{Cd} 6$ (1.728) and isolate $\mathrm{Cd} 2$ (1.509). The bacterial density that had been altered from the Optical Density (OD) value, then sort from highest to lowest namely isolate Cd 5 $\left(1.58 \times 10^{9}\right)$; isolate $\mathrm{Cd} 3\left(1.54 \times 10^{9}\right)$; isolate $\mathrm{Cd} 7\left(1.49 \times 10^{9}\right)$; isolate $\mathrm{Cd} 6\left(1.38 \times 10^{9}\right)$ and isolate Cd 2 $\left(1.21 \times 10^{9}\right)$. The difference in Optical Density (OD) showed the level of bacterial density. Bacterial growth can be seen from the level of turbidity (optical density) which can be read through the resulting absorbance value. The wavelength used is $600 \mathrm{~nm}$, that is the optimal wavelength in reading the density of the bacterial suspension.

The binding of heavy metals by bacteria can be separated into the binding phase and active transport. The binding phase depends on cell metabolism, namely absorption through the cell wall or external surface, then followed by active transport which depends on cell metabolism. In metabolic processes, heavy metals can accumulate in cell membranes (extracellular) and in the cytoplasm (intracellular) ${ }^{14}$. The bacterial isolates then selected into 3 bacteria with the highest density level to proceed the identification stage of the molecular method using $16 \mathrm{~S}$ rRNA. Those bacterial isolates are $\mathrm{Cd} 5, \mathrm{Cd} 3$, and Cd 7 isolates. 
DNA Extraction. DNA extraction is an early stage in molecular analysis. The objectives of DNA extraction is for separate nucleic acids from other components of the cell and obtain DNA concentration and purity values before proceeding to the next stage of the process. Good-quality of DNA purity is indicated by the value of protein and RNA contamination in the solution. The results of DNA purity and concentration are listed in Table 4.

\begin{tabular}{ccc}
\hline Sample Code & Concentration $(\mu \mathrm{g} / \mathrm{ml})$ & Purity (A260/A280) \\
\hline Cd 3 & 847.9 & 1.65 \\
Cd 5 & 1352.3 & 1.63 \\
Cd 7 & 355.5 & 1.44 \\
\hline
\end{tabular}

Table 4. DNA Purity and Concentration

Based on the measurement results, the purity of DNA isolate $\mathrm{Cd} 3$ is 1.65; isolate $\mathrm{Cd} 5$ is 1.63; and isolate $\mathrm{Cd} 7$ is 1.44 . The purity values of the three samples are deficient with purity values less than $1.8-2.0$ which indicates protein contamination. In DNA purity, a DNA sample classified into pristine if the absorbance value of 260 against the absorbance value of 280 is between $1.75-2.0$, but if the ratio is 2.0 then DNA still contains RNA ${ }^{15}$. The DNA band will absorb UV light at a wavelength of $260 \mathrm{~nm}$, while contaminants in the form of proteins or phenol compounds will absorb light at a wavelength of $280 \mathrm{~nm}$ so that the purity of the DNA solution can be measured from the ratio value between the absorbance at a wavelength of $260 \mathrm{~nm}$ (A260) with the absorbance value at a wavelength of $280 \mathrm{~nm}$ (A280) ${ }^{16-17}$.

DNA amplification. The purpose of DNA amplification is the in-vitro multiplication of pieces of DNA in a specific area bounded by two oligonucleotide primers. The primers used in this PCR process are $16 \mathrm{~S}$ rRNA 9F (5'-GAGTTTGATCCTGGCTCAG-3') and 1542R (5'-AGAAAGGAGGTGATCCAGCC-3') with a target DNA band size of $1500 \mathrm{bp}$. The DNA marker used was the DNA ladder $1 \mathrm{~kb}$. The amplified DNA visualized by electrophoresis on $1 \%$ agarose gel. The results of DNA electrophoresis showed positive results with the formation of DNA bands in agarose gel with the appropriate size target.

Genomic DNA electrophoresis used a $1 \mathrm{~kb}$ marker with a band display of $250-10,000 \mathrm{bp}$ ranges. The results of visualization in Fig. 4 show that the DNA band measuring 1,500 bp (base pair) matches the target. The DNA bands obtained were accordance with the target because the annealing temperature that had been optimized in the PCR program for the DNA amplification process was appropriate and running well. The results of electrophoresis of genomic DNA as a whole apart from the visible DNA bands showed a smear but too thin. Smears can be seen in all three isolate samples. Smears can be caused due to the presence of contaminants such as protein or carrying the remaining solution in the isolation process. According to previous study ${ }^{18}$, the smear could be the residue of the solutions that were still carried during the isolation process or it could also be DNA which was degraded in the isolation process.

\section{Analysis of Nucleotide Sequence Alignment from Sequencing Using NCBI GenBank Database. DNA} amplification results were sequenced by $1^{\text {st }}$ BASE in Singapore. The sequencing data obtained are the forward and reverse sequences of nucleotide bases. The sequencing data were processed using BioEdit software which was then identified by the BLAST (Basic Alignment Search Tools) program on the NCBI 
(National Center for Biotechnology Information) website. The detail of sequencing results are listed in Supplementary Table 2.

Results of BLAST program identification processed with BioEdit software showed that the Cd 3 isolate was identical to the Pseudoalteromonas issachenkonii strain KMM 3549 (Accession number NR 025139.1 ) with a query cover value of $85 \%$, e-value 0 and an identity value of $77.28 \%$. The bacterial isolate Cd 7 was identical to Pseudoalteromonas spiralis strain Te-2-2 (Accession number NR 114801.1) with a query cover value of $91 \%$, an e-value of 0 , and an identity value of $95.88 \%$. From 3 samples of DNA amplification results, 2 samples were successfully sequenced. 1 st BASE could not read the Cd 5 isolate


needs).

Query coverage is the percentage of nucleotide lengths that correspond to the database contained in BLAST. Query coverage is an important parameter because it rates in percent of sequences in the database masked queries, which confirms whether the sample is covered by all sequences. The cover query values of the isolates were $85 \%$ and $89 \%$. The acceptable percentage is at least $95 \%$, except for sequences where a lower reading is applied to a minimum of $75 \%{ }^{19}$.

The BLAST results of the two isolates had $77 \%$ and $97 \%$ identity values. A bacterial species can be said to be the same if it has a homology of more than or equal to $97 \%$. According to previous study about DNA sequence analysis ${ }^{21}$ and based on 16 S rRNA gene sequence data, identity $\leq 97 \%$ can be stated that the isolates being compared are in the same genus, identities between 89 - 93\% indicate different families. The BLAST results on NCBI said that the Cd 7 isolate is a Pseudoalteromonas spiralis strain Te$2-2$ because it has an identity value of $97 \%$ with Acc. No. NR 114801.1. Cd 3 isolate has an identity value of $77 \%$, it is suspected that this isolate is a new species that is in the same order, namely Alteromonadales.

The e-value of the two isolates is zero respectively. The e-value 0 obtained shows a significant alignment, which means that the search for the specimen sequence in this study is identical, namely from the same genus and even at the species level ${ }^{22}$. The higher the e-value indicates the lower the homology level between the sequences, while the lower the E-value indicates the higher the homology level between the sequences. An e-value of 0 (zero) indicates that the two sequences are identical.

Pseudoalteromonas issachenkonii strain KMM 3549. The bacteria species of Pseudoalteromonas issachenkonii strain KMM 3549 include the genus Pseudoalteromonas bacteria, the order Alteromonadales, the Gammaproteobacteria class, and the proteobacteria phylum. This species has heterotrophic and aerobic properties ${ }^{23}$, one of the proteobacteria groups that are abundant and widely distributed in the marine environment. This species grows at a temperature of $4-37^{\circ} \mathrm{C}$ and pH of 6.0 10.0. The optimum growth is at a temperature of $28-30^{\circ} \mathrm{C}$ and an optimum pH of $7.5-8.0$. Species cannot grow at temperatures over $40^{\circ} \mathrm{C}$. This species is a gram-negative bacterium, spindle-transparent colony form, rod-shaped cells, non-endospore, $0.7-0.9 \mu \mathrm{m}$ in diameter, and 1 - $1.2 \mu \mathrm{m}$ in length. 
The species Pseudoalteromonas issachenkonii strain KMM 2549 (Accession Number NR 025139.1) first isolated from the brown algal thallus (Fucus evanescens) collected in Kraternaya Bay, Kurile Islands in the Pacific Ocean ${ }^{24}$. Based on the isolation results obtained by previous study ${ }^{25}$, the $\mathrm{Cd} 3$ bacterial isolate has morphological characteristics in the form of bacilli (rods), the colony is in the form of spindles, is transparent white, and has gram-negative properties. These morphological characteristics are in accordance with the morphological characteristics of Pseudoalteromonas issachenkonii strain KMM 2549 (Accession Number NR 025139.1).

Pseudoalteromonas tetraodonis GFC strain IAM 14160. The bacterial species Pseudoalteromonas tetraodonis GFC strain IAM 14160 include the genus Pseudoalteromonas bacteria, the order Alteromonadales, the Gammaproteobacteria class, and the proteobacteria phylum. This species grows at a temperature of $4-35^{\circ} \mathrm{C}$ and a pH of 5.5 - 9.5. The optimum growth is at a temperature of $25-30^{\circ} \mathrm{C}$ and an optimum pH of $7.5-8.0$. Species cannot grow at temperatures over $40^{\circ} \mathrm{C}$. These species are gramnegative, aerobic, rod-shaped, non-endospore, and flagellated cells.

This bacterium was first isolated from puffer fish mucus (Fugu poecilonotus) to show tetrodoxin (a toxincarrying species) in association with biota ${ }^{26}$. Pseudoalteromonas in 1990 was classified as Alteromonas tetraodonia, but was reclassified in 2001 to the genus Pseudoalteromona. Based on the isolation results obtained by previous study 27 , the $\mathrm{Cd} 7$ bacterial isolate has rod-shaped morphological characteristics and has gram-negative properties. These morphological characteristics are in accordance with the morphological characteristics of Pseudoalteromonas tetraodonis GFC strain IAM 14160 (Accession Number NR 041787.1).

Phylogeny Analysis. Phylogenetic tree construction aims to see the relationship between the sample organisms based on their evolutionary relationships with the sequence of comparison organisms originating from the NCBI site. Phylogenetic trees were constructed using the neighbour-joining tree method. Phylogenetic trees were statistically tested using the bootstrap method with 1,000 replications. A bootstrap value of 100 to 1,000 replicates is used to estimate the confidence level of a phylogenetic tree $^{26}$. bootstrap analysis with values of $70 \%$ or higher indicates a reliable clustering ${ }^{28}$.

The construction of the phylogeny tree shows that the $\mathrm{Cd} 3$ sequence is related to Pseudoalteromonas issachenkonii strain KMM 3549 (Fig. 5a). The phylogeny tree also shows a kinship relationship between the two high sequences with a bootstrap value of $100 \%$ and an identity of $77 \%$. This value indicates that out of 1000 reconstructed phylogeny trees, the $\mathrm{Cd} 3$ sequence has a 100\% relationship with Pseudoalteromonas issachenkonii strain KMM 3549. On the other hand, the $\mathrm{Cd} 7$ sequence is related to Pseudoalteromonas tetraodonis GFC strain IAM 14160 (Fig. 5b). The phylogeny tree also shows a kinship relationship between the two high sequences with a bootstrap value of $99 \%$ and an identity of $97 \%$. This value indicates that from 1000 reconstructed phylogeny trees, the $\mathrm{Cd} 7$ sequence was $99 \%$ related to Pseudoalteromonas tetraodonis GFC strain IAM 14160.

\section{Methods}


Sampling. Sediment sampling was carried out from Northern Coast Indramayu, Indonesia more accurately at Karangsong Harbor, Indramayu Regency, West Java, Indonesia with coordinates S $06^{\circ} 56^{\prime} 2^{\prime \prime}$ E $107^{\circ} 46^{\prime} 38^{\prime \prime}$ using a piston core and a shovel. Samples were taken at ports contaminated with heavy metal Cadmium (Cd) in places that were immersed by water. Samples were taken at a depth of approximately $50 \mathrm{~cm}$ above sea level.

Cadmium Concentration Reduction Test (Cd). Seawater was filtered with a $0.22 \mu \mathrm{m}$ filter then sterilized using an autoclave put into a test bottle with a volume of $500 \mathrm{ml}$, close the bottle so that no air or other intervention disturb the seawater and let it rest. A stock solution of $\mathrm{Cd}\left(\mathrm{SO}_{4}\right)$ with a concentration of 1.5 $\mathrm{mgL}^{-1}$ (treatment A), $1 \mathrm{mgL}^{-1}$ (treatment $\mathrm{B}$ ) and $0.5 \mathrm{mgL}^{-1}$ (treatment $\mathrm{C}$ ) were added to the seawater in different tubes to pinpoint each treatment's effect on the result. Then the source of bacteria of about 10 $\mathrm{mL}$ was added into each of the test medium and homogenized. After that, the medium is then poured into an $80 \mathrm{ml}$ vial bottle quickly and precisely and labeled starting from $T_{0}$ or 0 hours, $T_{2}$ or 6 hours, $T_{3}$ or 12 hours, $T_{4}$ or 24 hours, and $T_{5}$ or 48 hours. The metabolism of the bacteria was stopped using $96 \%$ alcohol every hour.

Calculation of Bacterial Density. The calculation of bacterial density in this study was carried out using the Total Plate Count (TPC) method. The principle of the Total Plate Count (TPC) method is to grow living microbial cells on one or more media so that these cells multiply and form colonies that can be seen directly with naked eyes without using a microscope, and colonies can be counted using colony counter.

Inoculation of Bacteria. Bacterial inoculation is done by mixing the bacterial sample from pore water and then diluting it to $10^{-5}$. Then carried out the observation of the morphology of bacteria on the growth media (nutrient agar) using the pour plate method.

Gram stain. Gram staining will classify bacteria into two groups, namely gram-positive and negative. The final result is gram-positive bacteria marked in purple while gram-negative bacteria are marked in pink.

Cadmium Metal Challenge Test (Cd). This challenge test against heavy metals is to see the resistance of bacteria to heavy metals. Isolate of 8 bacterial were taken in one loop, put into $10 \mathrm{~mL}$ of liquid medium (Nutrient Broth) containing $\mathrm{Cd}\left(\mathrm{SO}_{4}\right)$ with concentrations of $1,1.5$ and $2 \mathrm{mg}$. $\mathrm{L}^{-1}$. Then the Optical Density (OD) value was measured using a spectrophotometer. Bacterial isolates were incubated into the incubator shaker for 18 hours at $37^{\circ} \mathrm{C}$ at a speed of $220 \mathrm{rpm}$. After that, the final Optical Density (OD) value was measured to determine the change in the density level of each bacteria.

Extraction of bacterial DNA. Extraction of bacterial DNA was done using the phenol chloroform method, but on the homogenization stage (cell lysis stage), reagents from TRIsure was used. The procedure used is based on the bacterial DNA extraction protocol from TRIsure BIOLINE. The stages of DNA extraction include homogenization, separation phase, DNA precipitation, DNA wash, and DNA re-dissolving.

Quantification of DNA Purity and Concentration. The purity of the extracted DNA was then measured using spectrophotometer at wavelengths (『) A260 nm and A280 nm. DNA purity can be calculated by 
dividing A260 by A280. The DNA concentration can be calculated by multiplying A250 by the dilution factor.

DNA amplification (PCR). Polymerase Chain Reaction (PCR) levels aim to increase DNA in-vitro. The primers used were $16 \mathrm{~S}$ rRNA universal primers, namely 9F (5'-GAGTTTGATCCTGGCTCAG-3', $T_{m} 58^{\circ} \mathrm{C}$ ) and 1542R (5'-AGAAAGGAGGTGATCCAGCC- 3 ', $T_{m} 62^{\circ} \mathrm{C}$ ). PCR reagents use kits from Promega, namely GoTaq $\mathrm{G} 2$ Green Master Mix list in the Supplementary Table 3 in detail. Meanwhile, mixed PCR reagents (PCR cocktails) are then amplified with the following program can be seen in Supplementary Table 4.

Electrophoresis. The concentration of agarose gel used was $1 \%$ at $35 \mathrm{ml}$ of $1 \times$ TAE buffer for amplified DNA electrophoresis. The staining gel used is Syber Safe Deoxyribonucleic Acid (DNA) staining (Thermofisher) with a ratio of 1:10,000. DNA ladder used measures $1 \mathrm{~kb}(10,000 \mathrm{bp})$ as much as $2 \mu \mathrm{l}$ with a target of DNA tape size of $\pm 1,500 \mathrm{bp}$. DNA as a result of amplification dielectrophoretic of $2.5 \mu \mathrm{l}$ and mixed with loading dye (weight) of $0.5 \mu \mathrm{l}$. Running at 100-volt voltage and $100 \mathrm{~mA}$ current for 30 minutes. Agarose gel was transferred to a UV transilluminator to observe the formed band.

Data analysis. DNA extraction results in absorbance measurements at wavelengths A260 and A280. The range of DNA purity is explained as follows:

$<1.8=$ protein contamination occurs (debris cell)

$1.8-2.0=$ pure

$>2.0=$ RNA contamination occurs (nucleic acids)

Sequencing \& BLAST. DNA sequencing aims to determine the sequence of nitrogen bases (adenine, guanine, cytosine, and thymine) of a DNA sample ${ }^{29}$. The sequencing method used is Sanger in First Base. The sequencing results obtained are then sorted using BioeditTM software ${ }^{30}$. The sequencing results are then uploaded to the gene bank through the BLAST program at the National Center of Biotechnology Information website (https://blast.ncbi.nlm.nih.gov/Blast.cgi)

Phylogenetic Analysis. Phylogenetic analysis of the nucleotide sequence aims to identify the ancestors and kinship of the organism ${ }^{31}$. This analysis uses MEGA X software.

\section{Conclusion}

Based on the results of the research that has been done, it can be concluded that, there are two isolates of cadmium (Cd) concentration-reducing bacteria from Karangsong Beach sediment, namely $\mathrm{Cd} 3$ bacterial isolates identical to Pseudoalteromonas issachenkonii strain KMM 3549 (Acc. No. NR 025139.1 ) with $77 \%$ identity value and $100 \%$ kinship value, and isolate $\mathrm{Cd} 7$ was identical to Pseudoalteromonas tetraodonis GFC strain IAM 14160 (Acc. NR 041787.1) with an identity value of $97 \%$ and a kinship value of $99 \%$. There are needs for further research on $\mathrm{Cd} 3$ isolates which are suspected to 
be a new species. Regarding the concentration of cadmium (Cd) reducing bacteria whose types and relationships are known, it is necessary to test on a field scale so that it can be applied to aquatic ecosystems that are heavily polluted by metal cadmium (Cd).

\section{Declarations}

\section{Acknowledgements}

This research was supported by Universitas Padjadjaran and Directorate General of Higher Education, the Ministry of Education and Culture, Indonesia with internal grant contract No.603/UN6.M/LT/2018.

\section{Author Contribution}

Y.N.I: Conceptualization, Methodology, Supervision. T. D. K. P: Writing - Review and Editing. K.F: project administration, Writing - editing and finishing.

\section{Funding}

All sources of funding for the research supported by Universitas Padjadjaran and Directorate General of Higher Education, the Ministry of Education and Culture, Indonesia with internal grant contract No.603/UN6.M/LT/2018.

\section{Competing interests}

The authors whose names are listed above and involved in this study certify that they have NO affiliations with or involvement in any organization or entity with any financial interest and non-financial interest in the subject matter or materials discussed in this manuscript.

\section{Availability of Data and Materials}

The datasets used and/or analysed during the current study are available from the corresponding author on reasonable request.

\section{References}

[1] Suprapti, N. H., Bambang, A.N, Swastawati, F, and Kurniasih, R. A. Removal of heavy metals from a contaminated green mussel Perna Viridis (Linneaus, 1758)] Using Acetic Acid as Chelating Agents. Aquatic Procedia 7: 154-159. https://doi.org/10.1016/j.aqpro.2016.07.021. (2016).

[2] Rochyatun, E., Kaisupy, M. T, Rozak, A. Distribution of Heavy Metals in Water and Sediment in Cisadane Estuary Waters. Makara SAINS 10 (1) : 35-40. doi: 10.7454/mss.v10i1.151. (2006). [In Indonesian]. 
[3] Sanusi, H. S. Accumulation of Heavy Metals $\mathrm{Hg}$ and Cd in the Body of Milksfish (Chanos chanos orskal) Dissertation of the Postgraduate Faculty, IPB: Bogor. (1985) [In Indonesian]

[4] Rinanda, T. 2011. 16S rRNA Sequencing Analysis In the Field of Microbiology. Syiah Kuala Medical Journal, 11(3). http://jurnal.unsyiah.ac.id/JKS/article/view/3484. (2011). [In Indonesian]

[5] Nontji, A. Nusantara Sea. (Djambatan, 1987) [In Indonesian].

[6] Silver, S. Bacterial resistances to toxic metal ions - a review 1. Gene. 179: 9-19 https://doi.org/10.1016/S0378-1119(96)00323-X. (1996).

[7] Bruins, M. R., Bux, F.H., \& Kasan, C. Considerations for application of biosorption technology to remediate metal-contaminated industrial effluents. Water SA. 24: 129-135 (1998)

[8] Martins, B.L., Cruz C.V., Luna, A.S., and Henriques, C.A. Sorption and desorption of $\mathrm{Pb}^{2+}$ ions by dead Sargassum sp. Biomass. Biochemical Engineering Journal, Vol. 27, No. 3, p. 310-314. https://doi.org/10.1016/j.bej.2005.08.007 (2006).

[9] Leboffe, M.J., dan Pierce, B.E. Brief Microbiology Laboratory Theory \& Application 2nd Edition. (Morton Publishing, 2012).

[10] Schlegel, H.G. General Microbiology. Indonesian Edition. (Gadjah Mada University Press, 1994) [In Indonesian].

[11] Hughes, M.N. and Poole, R.K. Metals and Microorganism. (Springer, 1989)

[12] Sidharta, B. R. Introduction to Marine Microbiology. (Atma Jaya Yogyakarta University, 2000) [In Indonesia]

[13] Imamuddin, $\mathrm{H}$. Examination of Bacterial Resistance Against $\mathrm{HgCl}_{2}$ Isolated from Quarry of Gold in Pongkor, West Java. (Center for Biological Research-LIPI, 2011) [In Indonesian]

[14] Aminah, U., Fatmawati, N. Lead (Pb) Heavy Metal Biosorption Using Bacterial Biomass. Technoscience Journal, 12(1), 50 - 70. (2018) [In Indonesian]

[15] Sambrook J, Russell, D.W. Molecular cloning: a laboratory manual. (Cold Spring Harbor LaboratoryPress, 2001)

[16] Muladno. Genetic Engineering Technology, $2^{\text {nd }}$ Edition (IPB, 2010) [In Indonesian]

[17] Fatchiyah, et al. Molecular Biology Basic Principles of Analysis. (Erlangga, 2011) [In Indonesian].

[18] Mulyani, Y., Purwanto, A., Nurruhwati, I. Comparison of Several DNA Isolation Method for Early Detection of Koi Herper Virus (KHV) in Goldfish (Cyprinus carpio). Faculty of Fisheries and Marine 
Sciences, Universitas Padjadjaran. Akuatika Journal, Vol. II. (2011) [In Indonesian]

[19] Narita, V., et al. WEB-based Bioinformatics Analysis for Exploration of Chitosanase Enzymes Based on Similar Sequences. Journal of Al-Azhar Indonesia Science and Technology Series, 1(4). http://dx.doi.org/10.36722/sst.v1i4.84. (2012) [In Indonesia].

[20] Stackebrandt, E. and Goebe, B.M. A place for DNA-DNA reassociation and 16S rRNA sequence analysis in the present species definition in bacteriology. International Jurnal of Systematic Bacteriology 44: 846-849. doi: 10.1099/00207713-44-4-846. (1995).

[21] Drancourt M, et al. 16S-Ribosomal DNA Sequence Analysis of a Large Collection of Environmental and Clinical Unidentifiable Bacterial Isolates. Journal of Clinical Microbiology, p. 36233630. Doi: 10.1128/JCM.38.10.3623-3630.2000. (2000)

[22] Tindi, M., Mamangkey, N.G.F., Wullur, S. DNA Barcode and Molecular Phylogenic Analysis of Several Types of Bivalves from North Sulawesi Water Based on the COI Gene. Journal of Coastal and Tropical Seas, 1(2): 32-38. doi: https://doi.org/10.35800/jplt.5.2.2017.15050. (2017) [In Indonesian]

[23] Gauthier, G., Gauthier, M., and Christen, R. Phylogenetic analysis of the genera Alteromonas, Shewanella, and Moritella using genes coding for small-subunit rRNA sequences and division of the genus Alteromonas into two genera, Alteromonas (emended) and Pseudoalteromonas gen. nov., and proposal of twelve new species combinations. Int. J. Syst. Bacteriol, 45:755-761. https://doi.org/10.1099/00207713-45-4-755. (1995).

[24] Ivanova, E. P., et al. Pseudoalteromonas issachenkonii sp. nov., a bacterium that degrades the thallus of the brown alga Fucus evanescens. International Journal of Systematic and Evolutionary Microbiology. 52, 229-234. doi: 10.1099/00207713-52-1-229 (2002).

[25] Salafy, A. 2018. Reduction of Heavy Metal Cadmium (Cd) Concentration using Indigenou Bacteria in Indramayu Karangsong Aquatic Sediment. Thesisi. Marine Science, Faculty of Fisherie and Marine Science, Universitas Padjadjaran. http://repository.unpad.ac.id/frontdoor/index/index/docld/36501. (2018) [In Indonesian].

[26] Ivanova, E. P., et al. Retrieval of the species Alteromonas tetradonis Simidu et al. 1990 as Pseudoalteromonas tetradonis comb. nov. And emendation of description. International Journal of Systematic and Evolutionary Microbiology. 51, 1071-1078. doi: 10.1099/00207713-51-3-1071 (2001).

[27] Hall, B.G. Phylogenetic Trees Made Easy: A How - To Manual for Molecular Biologists. (Sinauer Associates, Inc. Sunderland, Massachusetts, 2001)

[28] Hillis, D.M. and Bull, J.J. An empirical test of bootstrapping as a method for assessing confidence in phylogenetic analyses. Syst. Biol. 42, 182-192. https://doi.org/10.2307/2992540 (1993) 
[29] Tasma, I M. Utilization of Genome Sequencing Technology to Accelerate Plant Breeding Program. J. Litbang Pert. 34(4), pp: 159-168. (2015).

[30] Arham, W. Identification of Local Isolate Symbion-Nematode Bacteria from Bromo, West Java Based on DNA Sequences Coding 16S rRNA. Thesis, Biologi department, Faculty of Mathematics and Science. Universitas Jember. (2015) [In Indonesian]

[31] Ward, D. A Natural Spesies Concepts for Procaryotes.Microbiology 1: 271-77. (1998).

\section{Figures}



(a)

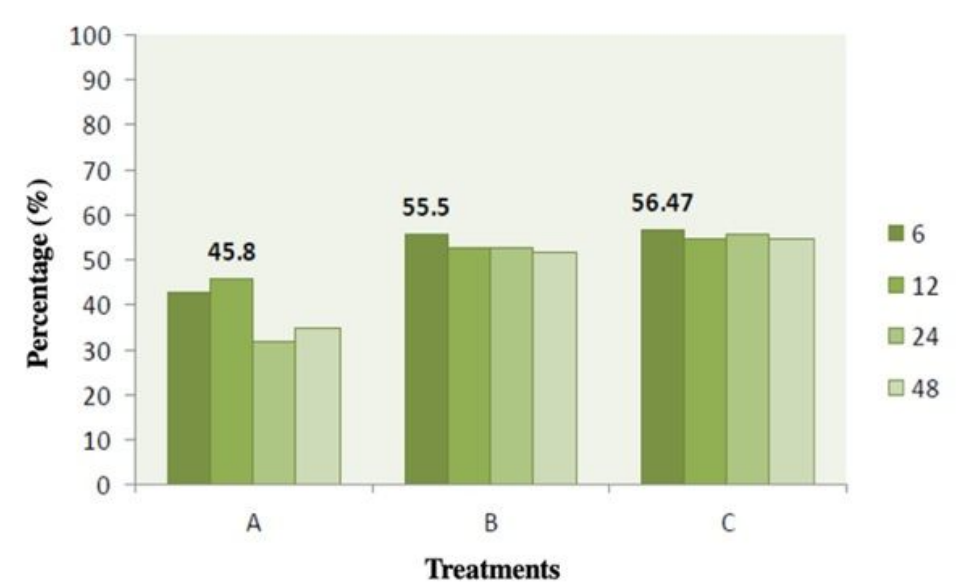

(b)

\section{Figure 1}

The Result of Cadmium (Cd) Metal Concentration Reduction Test. Bacterial reduction test was performed on three variations of heavy metal concentration namely $0.5 \mathrm{mg}$. L-1 (A), $1 \mathrm{mg}$. L-1 (B), $1.5 \mathrm{mg}$. L-1 (C) to determine the difference of reduction effectiveness. (a) Decrease in concentration of heavy metal $\mathrm{Cd}$ diagram (b) Bacterial reduction power diagram

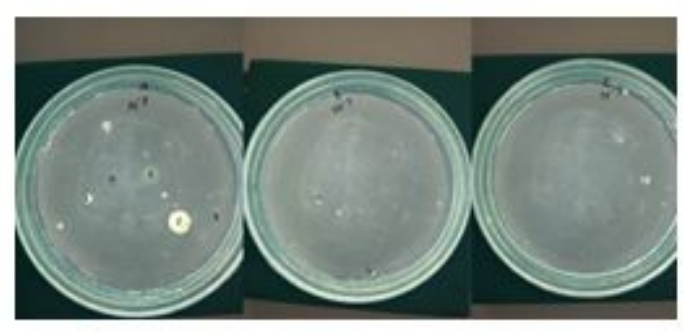

\section{Figure 2}

Culture of cadmium reduction bacteria. The isolation results obtained colonies that grow on the surface of the medium. Those bacteria are categorized as aerobic bacteria. 




\section{Figure 3}

Bacteria purification results. There are two differences in the color of bacterial colonies due to the excretion of substances or pigmentation into the medium.

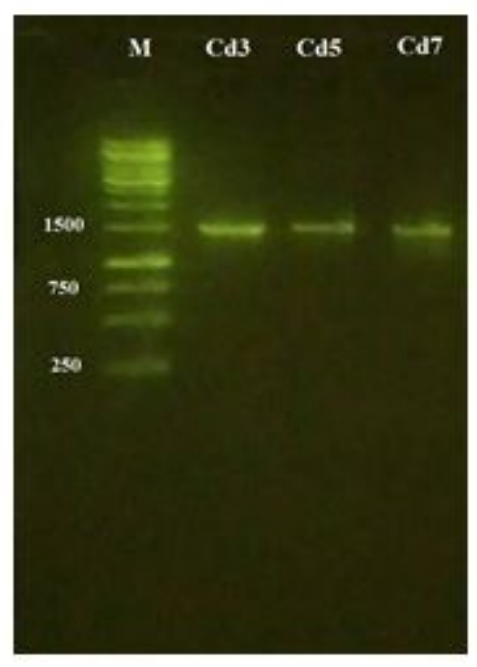

Figure 4

The result of agarose gel electrophoresis is $1 \%$ of the amplified DNA. The results of the three bacteria that had been extracted by DNA then amplified using the Polymerase Chain Reaction (PCR) method for 29 cycles. 


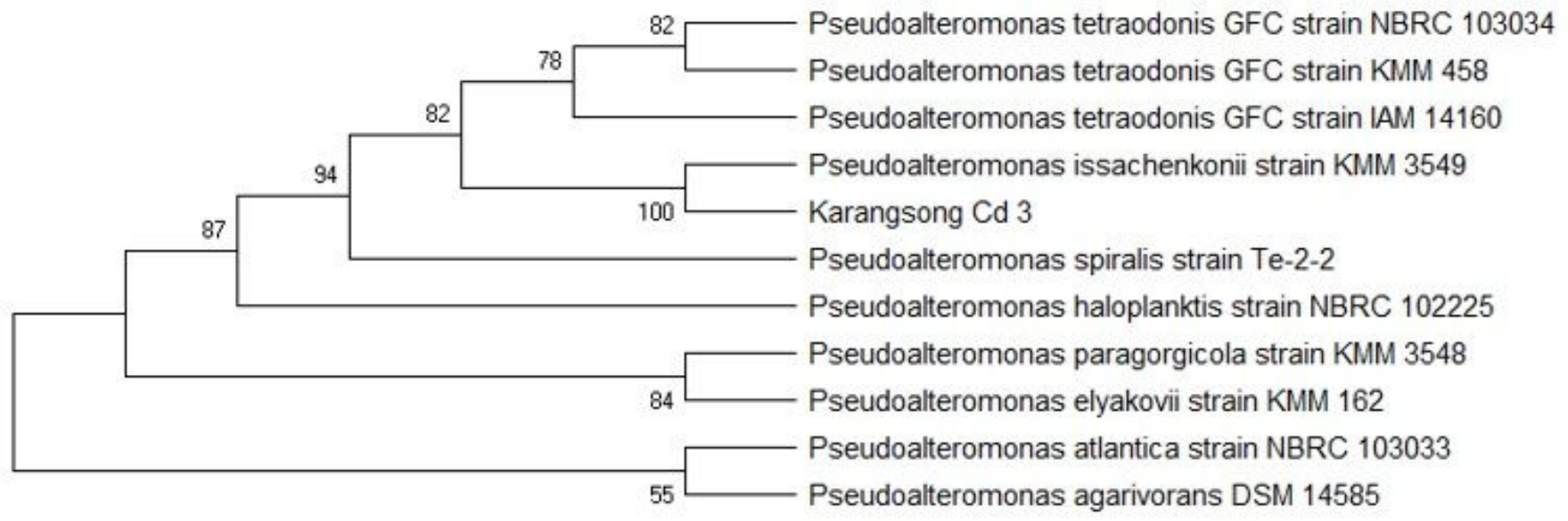

(a)

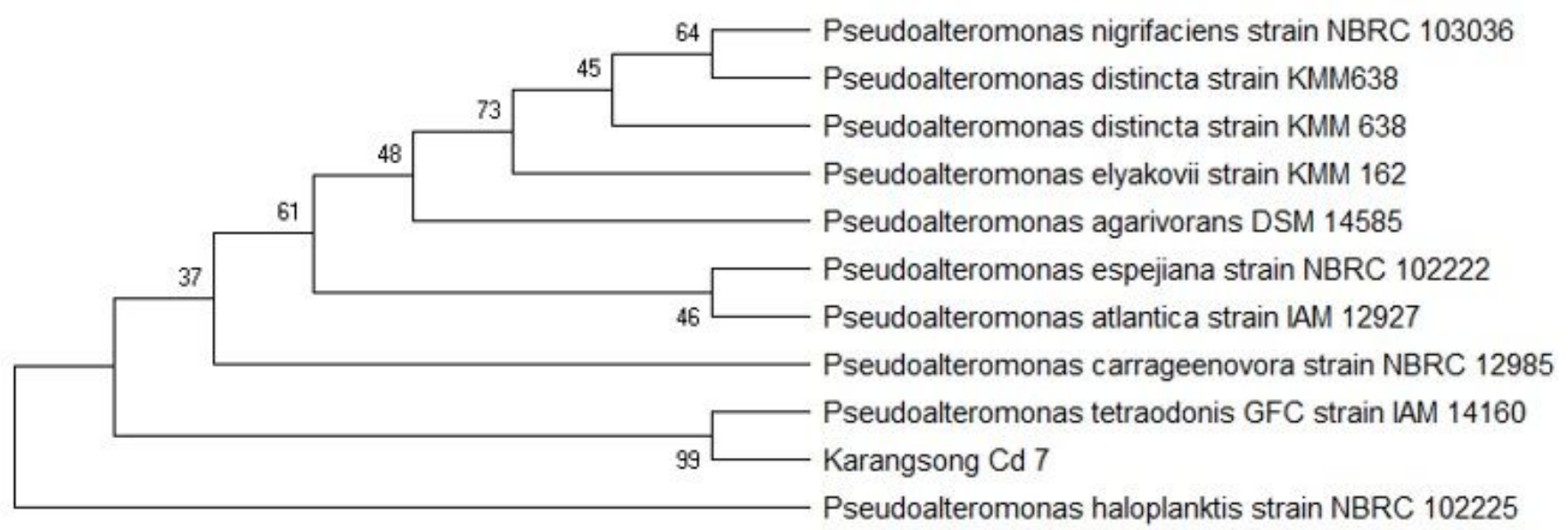

(b)

\section{Figure 5}

The Result of Phylogeny analysis from NCBI site to identified genetic relationship in which various groups of microorganisms. (a) Phylogeny tree of $\mathrm{Cd} 3$ and (b) Phylogeny tree of $\mathrm{Cd} 7$ bacterial isolates based on the neighbour-joining method 16S rRNA sequence, bootstrap 1000x.

\section{Supplementary Files}

This is a list of supplementary files associated with this preprint. Click to download.

- Supplementary.pdf 